Article

\title{
Ghivalry and Bushido, the Samurai Code
}

\author{
Shutaro Takeda*
}

\begin{abstract}
Chivalry is a concept that is both familiar and distant to many Japanese. There is no other social class in the world that resembles knights as much as the samurai in Japan. However, why is there such a gap between the behaviour of knights and samurais, even though they are both a social class with honor? This paper compares chivalry and Bushido, the Japanese Samurai code.
\end{abstract}

Keywords: Chivalry; Bushido; knighthood; samurai.

\section{Introduction}

What would you imagine when you hear the word "chivalry"? Often it is a knight on a white horse dressed in elegant attire, or gentlemanly behavior, or even courtly love with a lady. But all these elements of the chivalry are "impurities" of chivalry, added in the later years. The ancient chivalry of the High Middle Ages, when knights shined most brilliantly, was a far more stoic and barbaric discipline than we generally imagine.

In Western history, the Middle Ages can be divided into the Early Period (5th-10th centuries), the High Period (1 1th-13th centuries), and the Late Period (14th-15th centuries). During the High Middle Ages, the feudal system was firmly established as the social structure, the outline of the current group of states (Britain, France, Germany, Italy) was formed, and the population increased greatly. This period was also the time when Christianity launched a reversal of its long-standing struggle against the pagans. The best example of this was the Crusades, and the knights were the core force of this social movement that gathered the total power of the entire Christian world. The successful recapture of the Holy City in the First Crusade greatly raised the social status of the knights: they not only joined the ranks of the lower nobility, but an era arrived in which even princes sought the title of knight.

\section{Samurai}

On the opposite side of the Earth, in the land of the rising sun, a remarkably similar social class was also emerging in the same period. They were called Bushi, or later referred to more often as Samurai. I would not dive into details on the comparison between the western knight and the Japanese samurai in this paper, as it is a discussion that has been repeated numerous times prior to this paper. I would like to simply state that there is no other social class in the world that resembles knights as much as the samurai. However, at the same time, there seems to be no way of life more distant from the self-disciplined, low-key samurai than the silvertongued knight who dresses gorgeously and offers his love to a noblewoman. Why is it that there is such a gap between knights and samurais, even though they are both warriors with the same social status and honor? This paper compares chivalry and Bushido, the Japanese Samurai code, to trying to provide the answer. 


\section{Ghivalry by Gautier and Lull}

But before going into the comparison, I would like to first look back at the chivalry of the 11 th and 12th centuries by reiterating the "Ten Commandments of Chivalry" that Gauthier presented in "Chivalry," and compare and contrast them with the chivalry of the 13th century that Lull taught in "The Book of the Order of Chivalry."

Table 1. Comparison of the Gautier's Chivalry and Lull's Chivalry.

\begin{tabular}{l|l}
\hline $\begin{array}{l}\text { Ghivalry by Leon Gautier }(11 \text { th-12th } \\
\text { century chivalry) }\end{array}$ & $\begin{array}{l}\text { The Book of the Order of Ghivalry by } \\
\text { Ramon Lull (13th century chivalry) }\end{array}$ \\
\hline $\begin{array}{l}\text { The First Commandment: Thou shalt always } \\
\text { believe in the teachings of the Church and obey } \\
\text { its commands. }\end{array}$ & $\begin{array}{l}\text { (No one who does not love and revere God is } \\
\text { worthy of the honor of knighthood.) / A knight } \\
\text { who does not offer religious devotion is no less } \\
\text { damaging to himself. }\end{array}$ \\
\hline $\begin{array}{l}\text { Second Commandment: Thou shalt protect the } \\
\text { church. }\end{array}$ & $\begin{array}{l}\text { The duty of a knight is to protect and support } \\
\text { the faith of the Holy and Universal Church / A } \\
\text { knight who is the guardian of God's teachings to } \\
\text { save people. }\end{array}$ \\
\hline
\end{tabular}

The Third Commandment: Thou shalt honor the weak and be a protector of them.

A knight's duty is to protect the women, the widows, the orphans, the sick, and the weak.

The Fourth Commandment: Thou shalt love the nation of thy birth.

(No corresponding part)

The Fifth Commandment: Thou shalt not retreat in the face of the enemy.

The Sixth Commandment: Thou shalt fight the infidels with all thy might and with no mercy.

A cowardly knight who abandons his post and flees before the enemy... is one who disobeys his duty as a knight.

(No corresponding part)

The Seventh Commandment: Thou shalt strictly perform the duties of a vassal insofar as they do not violate the law of God.

A knight's duty is to serve and protect his lord. / A knight must help his lord.

Eighth commandment: Thou shalt not speak falsehoods, but be true to thy vows.

Those who bear false witness are not worthy of being knighted. Knights have a responsibility to be more sincere and pleasant to God and people.

The Ninth Commandment: Thou shalt be generous and give to all.

Chivalry and generosity are inseparable. A knight must give to the people with his hands as befits his honor and spare no money.

The Tenth Commandment: Thou shalt always stand on the side of righteousness and goodness against injustice and evil at all times.

Justice is the principle to which all knights should devote themselves / The knight's one duty now is to seek out and punish thieves, bandits, and evildoers. 
(No corresponding part)

The knight restores benevolence and order to the world through love. / Benevolence is the form of love required of the knight in the performance of his duties.

(No corresponding part) In the examination of a squire, one's manners and behavior must be tested.

The earliest Chanson de geste that Gauthier used as the basis for his Ten Commandments (the Song of Roland) were written at the end of the eleventh century, and there are nearly two hundred years between the chivalry taught by the two. In spite of this, the comparison on the right clearly shows that there is an almost one-to-one contrast between the two. This shows that the philosophy of chivalry was remarkably consistent throughout the Middle Ages.

However, there are some minor but important differences between the two teachings, and from these we can grasp the important implications that lead to the subsequent transformation of chivalry.

The teachings that Gautier had but Lull did not are "patriotism" and "war against infidels. It is the unanimous view of later scholars, including Florrie, that the patriotism teaching was a creation of Gautier to inspire the French people, and therefore it is not important that it is not included in Lull's teaching. The more essential difference lies in the omission of the "war against the pagans". It is no exaggeration to say that for the knights, the height of the Middle Ages was the time of the Crusades, but this campaign to retake the Holy Land with the Muslims as their opponents was not entirely successful, except for the first time. Especially in the 13th century, the Christian side was clearly outnumbered, and with the fall of Acre in 1921, the Kingdom of Jerusalem was destroyed and the achievements of the Crusades were burnt to ashes. After this, the interest of Christian monarchs shifted to the struggle between nations, and with the start of the Hundred Years' War in 137, the era of Christian knights washing each other's blood with blood arrived. The fact that "fighting against the pagans" was dropped from Lull's chivalry can be read as a foretaste of such a decline.

On the other hand, there are some key words that are newly observed in Lull's chivalry. The first of these is "love". The Book of the Order of Chivalry tells us that knights are the ones who "restore benevolence and order to the world through love," and repeatedly describes the kind of love that knights should have. This is a concept that cannot be found in Gautier's chivalry of the eleventh and twelfth centuries, which was fundamentally a discipline for warriors, and it is an important beginning to the more courtly chivalry that followed. The other key word is "civility". Lull mentions civility as a prerequisite for knighthood, which reflects the changing world of the time when knights were seen as role models for the common people. "As the sentence "If the knight does not make mistakes, the common people will not make mistakes either" clearly shows, this phrase "civility" well expresses the tone of the 13th century, when the requirements for knights were shifting from being "horsemen" to being "noble."

\section{From Medieval Ghivalry to Early Modern Ghivalry}

In order to deepen our understanding of chivalry in the Middle Ages, it is important to understand that Jesus Christ was the supreme lord and the only king for the knights of that time. "God, the blessed and only Ruler, the King of kings and Lord of lords," (1 Timothy 6:15). Therefore, in Europe during the height of the Middle Ages, people shared the value 
that no matter how many kingdoms the earth was divided into and how many kings ruled over them, they were all part of a single Christendom with God in heaven as the sovereign.

If we understand this fundamental value, we can understand that in the Ten Commandments for knights, "devotion and obedience to God" is placed higher than "vassalage to the earthly lord" as a natural truth. This is the reason why knighthood was regarded as a covenant with God in the Middle Ages, and why the Seventh Commandment commands, "Thou shalt strictly fulfill the duties of vassalage insofar as they do not violate the law of God." In other words, the fusion of feudal values that commanded obedience to the lord and Christian values that stipulated that the God was the lord among lords formed the chivalry of the Middle Ages, in which devotion to God was the supreme principle.

However, this idea of "one Christian nation" rapidly faded away after the late Middle Ages. After a series of wars between Christians, the concept of modern nation was formed in the process, and nationalism took its shape. In addition, the monarchs of each country established orders of knighthood as secular, honorary organizations in order to attract influential people, and the value that being admitted to these orders became a social honor. Knights came to recognize that the monarch was the "source of honor" - not the God. Thus, the knights lost their sense of belonging to Christendom. Early modern chivalry was transformed into a discipline that commanded loyalty to an earthly lord rather than to a heavenly god.

Finally, in examining the transformation of chivalry, it is essential to discuss the great popularity of medieval knightly tales, led by the Arthurian legend. As Gauthier argues in the text, the spread of this literature from the late Middle Ages onward infused chivalry with courtly values and the romance of devotional love for noblewomen.

Thus, the discipline of the warrior in the height of the Middle Ages, with its core values of "devotion to God, fighting the infidels, and protecting the weak," was transformed hundreds of years later into the values of the courtier in the early modern era, with its core values of "loyalty to the lord, honor and civility, and love for noblewomen."

\section{Ghivalry and Bushido}

Having discussed the transformations of chivalry since the height of the Middle Ages, let us now turn our attention to the far-east, and compare chivalry to Bushido, the samurai code.

Bushido is a term comprised of bushi (samurai) and do (the way) - therefore, it literally means "the way of samurai." According to Satoshi Furukawa, the earliest appearance of the word bushido is in the 16th century Koyo Gunkan. Bushido, as expressed in this book, was a pure war philosophy that put winning first and teach never miss an opportunity to fight when it was necessary. In terms of the discipline, this Bushido is in line with the values of the Germanic peoples who places the highest priority on victory and military valor, the origin of chivalry.

As Japan enters Edo period (1603-1867) and civil warfare subsided, Bushido inevitably changed from a warrior's mindset to a Confucian way of life. The Bushido of the Edo period, which was based on the principles of loyalty, faith, and righteousness, was the moralistic counterpart of early modern chivalry. In the Sengoku period (1467-1603), bushido was used as a synonym for "man's way" and "samurai way," but in the Edo period it became known as "nobleman's way."

In Meiji era (1868-1912), Inazo Nitobe extracted the moral values from the Edo Bushido and infused them with a public spirit appropriate to the Meiji era, giving birth to the Meiji Bushido. Kakuaki Sugano argues that this was a change from the Bushido of private combatants to a national military unity and loyalty to the emperor. In this way, the Meiji 
Bushido, which teaches the values of a person who should stand as a role model above the people, has the same background as early modern chivalry, which was shaped by nationalism.

By tracing these changes, we can once again see the striking similarities between chivalry and bushido. The values of the Germanic peoples and warrior bushido were disciplines that went hand in hand in the mindset of the combatants. As time went by, they were indoctrinated, and both were transformed into moralistic values. Finally, this morality was infused with a public spirit based on nationalism, and the code of conduct for those who stood above the people was completed. In other words, although chivalry and bushido share the same source, they gradually lost their way in two ways: the difference in the values that formed their morality (Christianity and Confucianism) and the presence or absence of the romance element. Thus, in the East and West of the world, the two warrior paths of chivalry, which pursues "loyalty to the lord, honor and civility, and love for noblewomen," and bushido, which adheres to "loyalty to the lord, honor and respect, and the spirit of fair play," rose to prominence.

Table 2. Comparison of Chivalry and Bushido.

\begin{tabular}{|c|c|c|c|c|}
\hline & Chivalry & & Bushido & \\
\hline \multirow[t]{2}{*}{$\begin{array}{c}\text { Germanic } \\
\text { origin }\end{array}$} & $\begin{array}{l}\text { Valor on the } \\
\text { battlefield comes first, } \\
\text { never pull back. }\end{array}$ & $\begin{array}{c}\text { Sengoku } \\
\text { period } \\
(1467- \\
1603)\end{array}$ & $\begin{array}{l}\text { Victory comes first, } \\
\text { fight when you have } \\
\text { to. }\end{array}$ & $\begin{array}{l}\text { Principles of } \\
\text { behavior on } \\
\text { the battlefield }\end{array}$ \\
\hline & Christian influence & & $\begin{array}{c}\text { Influence of } \\
\text { Confucian thought }\end{array}$ & \\
\hline \multirow[t]{2}{*}{$\begin{array}{c}\text { Medieval } \\
\text { times }\end{array}$} & $\begin{array}{l}\text { Devotion to God, } \\
\text { fighting the pagans, } \\
\text { protecting the weak }\end{array}$ & $\begin{array}{c}\text { Edo } \\
\text { period } \\
(1603- \\
1867)\end{array}$ & $\begin{array}{l}\text { Loyalty to the lord, } \\
\text { integrity, acting for } \\
\text { the good of the world }\end{array}$ & Moral values \\
\hline & $\begin{array}{c}\text { Nationalism, } \\
\text { influence of medieval } \\
\text { knightly tales }\end{array}$ & & $\begin{array}{l}\text { Influence of } \\
\text { nationalism }\end{array}$ & \\
\hline $\begin{array}{l}\text { Modern } \\
\text { times }\end{array}$ & $\begin{array}{l}\text { Loyalty to the lord, } \\
\text { honor and civility, } \\
\text { love for noble ladies. }\end{array}$ & $\begin{array}{c}\text { Meiji era } \\
(1868- \\
1912)\end{array}$ & $\begin{array}{l}\text { Loyalty to the lord, } \\
\text { honor and respect, } \\
\text { and the spirit of fair } \\
\text { play }\end{array}$ & $\begin{array}{l}\text { Code of } \\
\text { conduct as a } \\
\text { person who } \\
\text { stands above } \\
\text { the people }\end{array}$ \\
\hline
\end{tabular}

\section{References}

Geoffroi de Charny, Richard W. Kaeuper, Elspeth Kennedy (2013), A Knight's Own Book of Chivalry, University of Pennsylvania Press

Francis Warre Cornish (1908), Chivalry, Swan Sonnenshein \& Co., Lim.

Léon Gautier (1884), La Chevalerie, Sanard et Derangeon

David Marcombe (2003), Leper Knights: The Order of St Lazarus of Jerusalem in England, c.1150-1544, The Boydell Press 
Jesus D. Rodriguez-Velasco (2016), Eunice Rodriguez Ferguson, Order and Chivalry, University of Pennsylvania Press

Peter Bander van Duren (1995), Orders of Knighthood and Merit: The Pontifical, Religious and Secularised Catholic-founded Orders and their relationship to the Apostolic See, Colin Smythe

Sir Bernard Burke (1858), The Book of Orders of Knighthood and Decorations of Honours of All Nations, Hurst and Blackett Publishers

Gunnar Boalt, Robert Erikson, Harry Gluck, Herman Lantz (1971), The European Orders of Chivalry, P A Norstedt \& Soners forlag Stockholm

D'Arcy Jonathan Dacre Boulton (1987), The Knights of the Crown: The Monarchical Orders of Knighthood in Later Medieval Europe 1325-1520, The Boydell Press

J. H. Lawrence-Archer (1887), ORDERS OF CHIVALRY: From the Original Statutes of the Various Orders of Knighthood, and other Sources of Information, W. H. Allen and Co.

Rajah Sir Sourindro Mohun Tagore (1884), The Orders of Knighthood, British and Foreign, with a Brief Review of the Titles of Rank and Merit in Ancient Hindusthan, Stanhope Press

Alister E. McGrath (2015), Christianity: An Introduction 3rd Edition, Wiley-Blackwell 